\title{
Diversification of processed yellow pumpkin products (Cucurbita Moschata) in efforts to develop household culinary businesses
}

\author{
Siti Khadijah Hidayati Nasution ${ }^{1 *}$, R.B.Moh Ibrahim Fatoni ${ }^{1}$ \\ ${ }^{1}$ Faculty of Agriculture, Universitas Sumatera Utara, Medan, Indonesia \\ *Email: dijah@usu.ac.id
}

\begin{abstract}
The development of SMEs in the culinary in Medan has increased every year. Market opportunities provide SMEs to grow. Diversification in food processing can be done by adding pumpkin (Cucurbita Moschata) into food dough food so that it becomes a different product from those in the market. YAAHFTICS is a SMEs which is engaged in culinary, especially birthday cake, pizza, roll cake and others. Mitra has been established since 2015. Partners rely on marketing through social media Instagram. In running the business cycle, partners experience several major problems. Starting in terms of business financial management, product diversification to the problem of quantity production. The aim of the Community Service Program activities is that Partners can increase their production capacity so that they can increase their income, able to produce diversified processed products from pumpkins, and able to determine product prices with optimal profit. The method of activity used is the delivery of production equipment, the practice of using production equipment to increase production capacity, the practice of making diversified processed pumpkin products and monitoring the production and sales processes. The results of the oven and mixer grant in this service activity can increase the partner's production capacity product. After counseling the importance of product diversification and the practise of diversification of pumpkin processed pumpkin products, the partner have been able to diversity their processed pumpkin products. And the partner have been able to determine product prices with optimal profit after the partner has been given training in determining the cost of goods sold.
\end{abstract}

\section{Keyword: Cucurbita Moschata, Diversification, SMEs}

\begin{abstract}
Abstrak
Perkembagan UMKM bidang pangan (kuliner) di Kota Medan mengalami peningkatan setiap tahunnya. Peluang pasar yang terbuka besar memberikan kesempatan UMKM untuk dapat tumbuh.Diversifikasi pada olahan pangan yang dapat dilakukan dengan memberikan tambahan Labu kuning (Cucurbita Moschata) kedalam adonan makanan pangan sehingaa menjadi produk yang berbeda dengan yang ada dipasaran.YAAHFTICS adalah UMKM yang bergerak di bidang kuliner khususnya cake ulang tahun, pizza, donat, bolu gulung dan yang lainnya. Mitra sudah berdiri mulai dari tahun 2015. Mitra mengandalkan pemasaran melalui media sosial Instagram. Dalam menjalankan business cycle, mitra mengalami beberapa permasalahan yang utama. Mulai dari segi manajemen keuangan usaha, diversifikasi produk sampai kepada permasalahan kuantitas produksi. Tujuan dari kegiatan. Program Pengabdian pada Masyarakat ini adalah Mitra mampu meningkatkan kapasitas produksinya sehingga dapat meningkatkan pendapatannya, mampu menghasilkan diversifikasi produk olahan dari labu kuning, dan mampu menentukan harga produk dengan keuntungan yang optimal. Metode kegiatan yang digunakan yaitu penyerahan peralatan produksi, praktek penggunaan peralatan produksi untuk meningkatkan kapasitas produksi, praktek pembuatan diversifikasi produk olahan labu kuning dan monitoring terhadap proses produksi dan penjualan.Hasil hibah oven dan mixer dalam kegiatan pengabdian ini dapat meningkatkan kapasitas produksi Mitra. Setelah adanya penyuluhan pentingnya diversifikasi produk dan praktek diversifikasi produk olahann labu kuning, Mitra telah mampu melakukan diversifikasi produk olahan dari labu kuning. Dan Mitra telah mampu menentukan harga produk dengan keuntungan yang optimal setelah Mitra diberi pelatihan penentuan harga pokok penjualan.
\end{abstract}

Kata Kunci: Cucurbita Moschata, Diversifikasi, UMKM 


\section{PENDAHULUAN}

Tingginya kebutuhan akan produk pangan, menyebabkan banyak peneliti berusaha untuk mencari pangan alternatif. Pangan alternatif yang selama ini sudah diseminasi masih kurang diminati oleh masyarakat dikarenakan bentuk dan rasa yang masih sulit untuk mempengaruhi konsumen beralih dari produk pangan pada umumnya. Kondisi ini sekaligus untuk menunjang program peningkatan ketahanan pangan. Program ini harus didukung dengan upaya pengembangan diversifikasi produk olahan yang menitik beratkan kepada penganekaragaman sumberdaya pangan (Suismono dan Hidayah, 2011)

Kebutuhan produk pangan akan selaras dengan perkembangan UMKM bidang pangan (kuliner). Perkembagan UMKM bidang pangan (kuliner) di Kota Medan mengalami peningkatan setiap tahunnya. Peluang pasar yang terbuka lebar memberikan kesempatan UMKM untuk dapat tumbuh. Diversifikasi produk dari UMKM menjadi kekuatan sebuah UMKM untuk dapat bertahan dalam persaingan pasar yang begitu ketat. Kondisi pasar yang hampir menuju pasar persaingan sempurna ini menyebabkan pelaku usaha harus bersaing secara sehat. Pengembangan UMKM dapat dilakukan dengan perluasan pasar, diversifikasi produk ataupun meningkatkan kapasitas produk. Diversifikasi produk merupakan suatu cara yang selain mampu mengembangkan UMKM namun juga mampu memberikan loyalitas terhadap konsumen.

Diversifikasi pada olahan pangan yang dapat dilakukan dengan memberikan tambahan Labu kuning (Cucurbita Moschata) kedalam adonan makanan pangan sehingaa menjadi produk yang berbeda dengan yang ada dipasaran. Labu Kuning adalah komoditi pertanian yang memiliki kandungan karbohidrat yang cukup untuk menjadi diversifikasi bahan pangan. Selain kandungan karbohidrat yang tinggi, labu kuning juga memiliki kandungan $\beta$-karoten atau provitamin-A yang bermanfaat bagi kehidupan serta kesehatan (Hendrasty, 2003). Labu kuning memiliki potensi yang cukup besar untuk dijadikan pangan alternatif. Hal ini mengacu kepada kandungan gizi dalam setiap $100 \mathrm{~g}$ labu kuning terdapat $29 \mathrm{kkal}$ energi, lemak $0.3 \mathrm{~g}$, protein $1.1 \mathrm{~g}$, karbohidrat $6.6 \mathrm{~g}$ dan vitamin A (Depkes, 1995). Kandungan karbohidrat ini relatif lebih rendah jika dibandingkan oleh kandungan karbohidrat yang ada pada komoditi pisang (Saragih, 2012). Pangan dengan nilai indeks glikemiks rendah akan membantu meningkatkan kesehatan (Widowati, 2007; Astawan dan Widowati, 2011). Hal ini yang akan diaplikasikan kepada mitra pengabdian kepada masyarakat.

YAAHFTICS adalah UMKM yang bergerak di bidang kuliner khususnya cake ulang tahun, pizza, donat, bolu gulung dan yang lainnya. Mitra sudah berdiri mulai dari tahun 2015. Mitra mengandalkan pemasaran melalui media sosial Instagram. Dalam menjalankan business cycle, mitra mengalami beberapa permasalahan yang utama. Mulai dari segi manajemen keuangan usaha, diversifikasi produk sampai kepada permasalahan kuantitas produksi. Dari segi manajemen keuangan, mitra masih kesulitan untuk melakukan perhitungan harga pokok penjualan yang dimana sebagai landasan penentuan harga jual yang relevan untuk ditetapkan oleh mitra.Dari segi produk, produk yang dihasilkan oleh mitra masih sangat monoton dan sangat mudah untuk dijumpai di masyarakat. Kondisi pasar yang semakin kompetitif menyebabkan mitra harus melakukan diversifikasi produk sehingga dapat menarik konsumen dan meningkatkan pendapatan. Selain itu, keberlanjutan dari usaha menjadi sangat penting. Diversifikasi produk menjadi sebuah keharusan dari sebuah usaha UMKM untuk dapat bertahan. Tujuan dari kegiatan Program Pengabdian pada Masyarakat ini adalah sebagai berikut:

1. Mitra mampu meningkatkan kapasitas produksinya sehingga dapat meningkatkan pendapatannya.

2. Mitra mampu menghasilkan diversifikasi produk olahan dari labu kuning.

3. Mitra mampu menentukan harga produk dengan keuntungan yang optimal

\section{METODE PELAKSANAAN}

YAAHFTICS adalah UMKM yang bergerak di bidang kuliner khususnya cake ulang tahun, pizza, donat, bolu gulung dan yang lainnya. Mitra sudah berdiri mulai dari tahun 2015. Mitra 
mengandalkan pemasaran melalui media sosial Instagram. Dalam menjalankan business cycle, mitra mengalami beberapa permasalahan yang utama. Mulai dari segi manajemen keuangan usaha, diversifikasi produk sampai kepada permasalahan kuantitas produksi. Dari segi manajemen keuangan, mitra masih kesulitan untuk melakukan perhitungan harga pokok penjualan yang dimana sebagai landasan penentuan harga jual yang relevan untuk ditetapkan oleh mitra.Dari segi produk, produk yang dihasilkan oleh mitra masih sangat monoton dan sangat mudah untuk dijumpai di masyarakat. Kondisi pasar yang semakin kompetitif menyebabkan mitra harus melakukan diversifikasi produk sehingga dapat menarik konsumen dan meningkatkan pendapatan. Selain itu, keberlanjutan dari usaha menjadi sangat penting. Diversifikasi produk menjadi sebuah keharusan dari sebuah usaha UMKM untuk dapat bertahan. Tujuan dari kegiatan Program Pengabdian pada Masyarakat ini adalah sebagai berikut:

1. Mitra mampu meningkatkan kapasitas produksinya sehingga dapat meningkatkan pendapatannya.

2. Mitra mampu menghasilkan diversifikasi produk olahan dari labu kuning.

3. Mitra mampu menentukan harga produk dengan keuntungan yang optimal

\section{HASIL DAN PEMBAHASAN}

Kegiatan pengabdian kepada masyarakat yang dilakukan oleh Tim pelaksana dibagi menjadi dua kegiatan. Tahap awal kegiatan pengabdian, Tim memberikan hibah alat penunjang proses produksi Mitra berupa oven 6 loyang dan mixer berkapasitas $1,5 \mathrm{~kg}$ sebagai salah satu cara untuk meningkatkan kapasitas produksi Mitra. Kegiatan ini Tim lakukan pada bulan Juli 2019 dengan melakukan pembelian oven 6 loyang dan mixer berkapasitas 1,5 kg dan langsung memobilisasinya ke lokasi Mitra serta langsung mempraktekkan cara penggunaannya. Selanjutnya oven dan mixer tersebut telah digunakan oleh Mitra untuk menghasilkan aneka ragam cake, bolu, pitza, dan aneka roti manis yang biasanya tidak mampu diproduksi Mitra karena keterbatasan alat produksi. Pada tahap kedua kegiatan pengabdian, tim melakukan pelatihan penentuan harga pokok penjualan, penyuluhan pentingnya diversifikasi produk, penyuluhan manfaat komoditas labu kuning, dan praktek/demo diversifikasi produk olahan labu kuning yang dilakukan di lokasi Mitra. Kegiatan tahap kedua ini diikuti oleh rekanan Mitra.Tahap I kegiatan pengabdian, tim melakukan diskusi bersama Mitra mengenai oven dan mixer seperti apa yang sesuai dengan kebutuhan Mitra serta sesuai dengan anggaran dana yang ada. Setelah itu Tim pelaksana bersama Mitra melakukan pemblian oven dan mixer yang sesuai dengan kebutuhan Mitra untuk meningkatkan kapasitas produksinya.

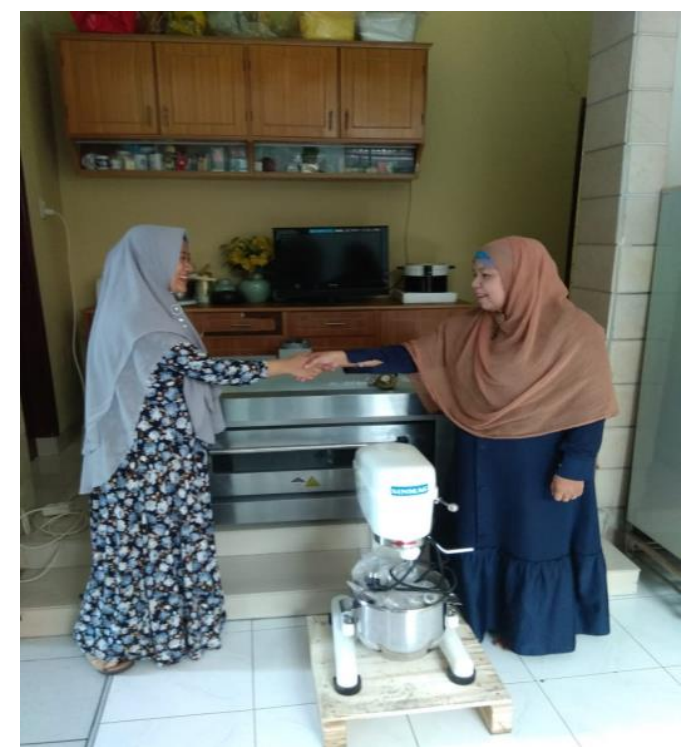

Gambar 3.1 Hibah Alat Berupa Oven dan Mixer 
Tim juga melakukan praktek penggunaan mesin oven yang menggunakan system digitalisasi. Selain itu, tim juga sudah memberikan resep produk olahan dari labu kuning yang bisa diimplementasikan oleh Mitra sehingga Mitra mampu melakukan diversifikasi produk olahan labu kuning. Hal ini dilakukan di tahap awal sebelum dilakukan praktek/demonstrasi diversifikasi produk olahan labu kuning agar Mitra dapat mempraktekkan terlebih dahulu resep yang telah diberikan Tim dengan menggunakan oven dan mixer yang telah dihibahkan Tim pelaksana pengabdian USU.

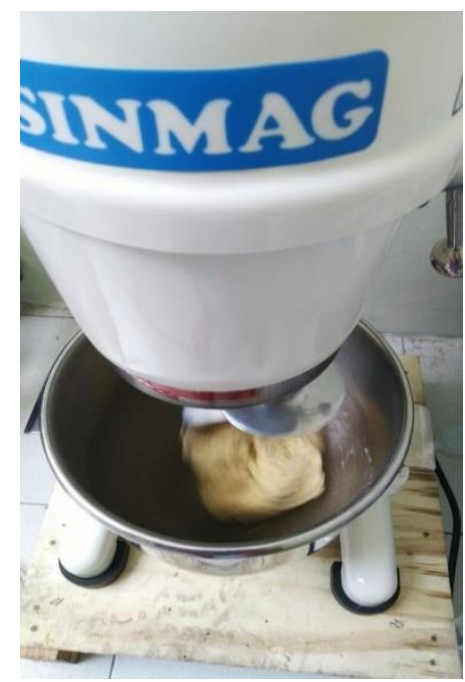

Gambar 3.2 Proses Penggunaan Mixer

Setelah beberapa hari tim melakukan monitoring terhadap proses produksi Mitra, Mitra telah mampu mengerjakan orderan/pesanan konsumen dalam jumlah yang relatif meningkat.. Mesin mixer yang telah dihibahkan mampu memproses $1,5 \mathrm{~kg}$ tepung dalam sekali proses pengadukan (mixing). Adanya mesin mixer ini telah mampu menghemat waktu proses produksi Mitra. Selain mixer, mesin oven yang telah dihibahkan kepada Mitra memiliki kapasitas 6 loyang dalam sekali proses pemanggangan dengan loyang berbentuk persegi panjang sedang jika terdapat kombinasi dengan loyang berbentuk bulat maka oven tersebut akan berkapasitas 5 loyang.

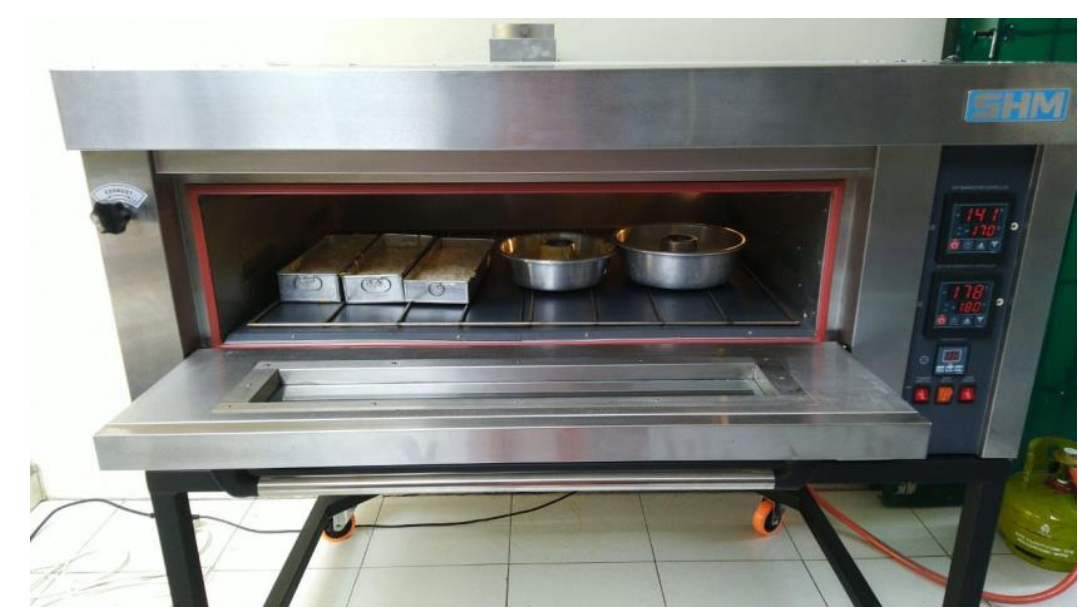

Gambar 3.3 Proses Pemanggangan dengan Menggunakan Oven Hibah Tim Pelaksana 


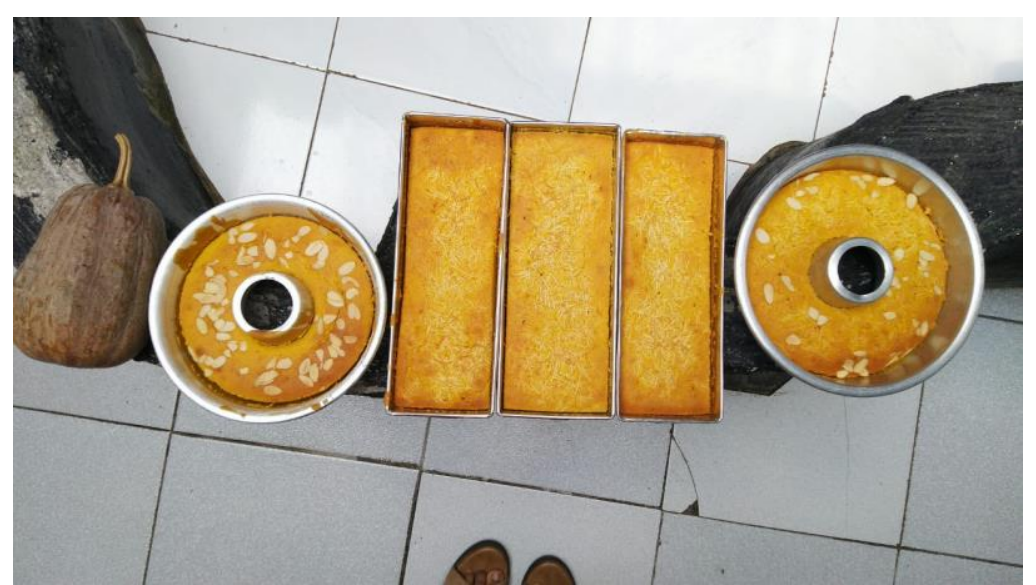

Gambar 3.4 Hasil/Output Pemanggangan dengan Menggunakan Oven Hibah Tim Pelaksana

Selain melakukan uji coba resep yang telah disampaikan oleh tim, Mitra juga melakukan uji coba dengan menghasilkan beberapa produk baru seperti roti-roti manis yang sebelumnya tidak mampu diproduksi oleh Mitra karena keterbatasan alat produksi yang dimiliki Mitra. Setelah adanya oven dan mixer yang diberikan oleh tim pelaksana, Mitra telah mampu melakukan inovasi dan diversifikasi pada produk olahannya.
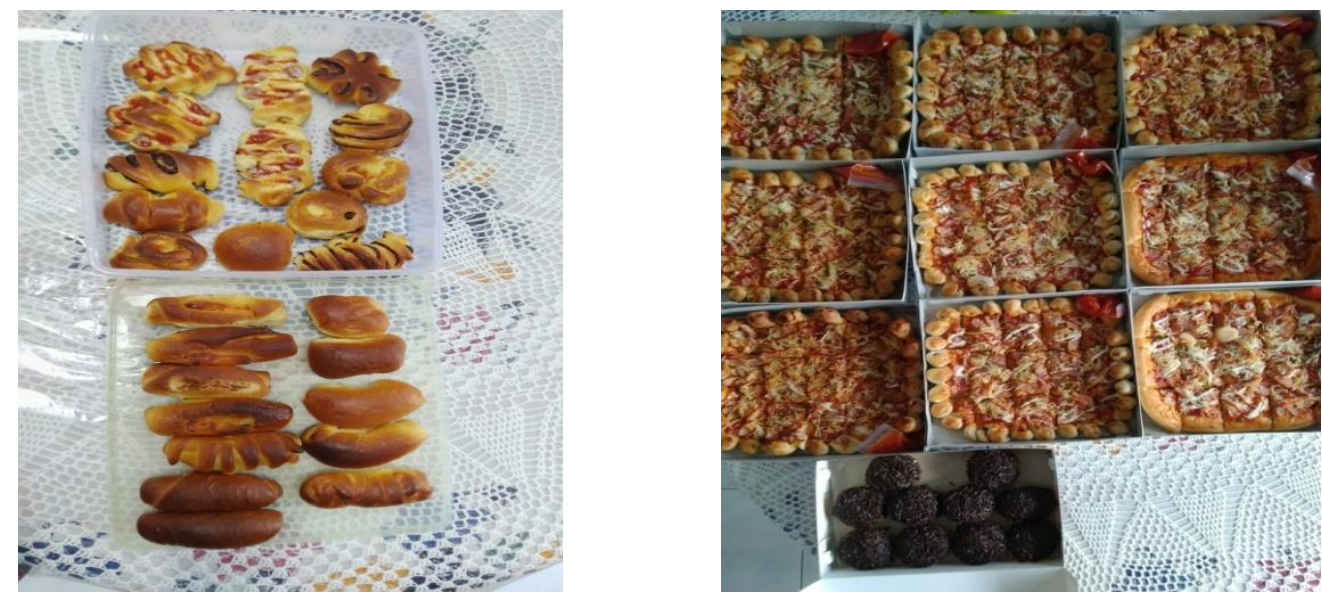

Gambar 3.5 Hasil Produk Olahan Selain Bolu

Kegiatan pengabdian selanjutnya adalah pelatihan penyusunan harga pokok penjualan. Instruktur Pelatihan Penyusunan Harga Pokok ini adalah R.B.M. Ibrahim, M.Si., MP. Pelatihan Penyusunan Harga Pokok ini diberikan kepada Mitra agar Mitra mampu menentukan harga produk yang optimal sehingga dapat memberikan keuntungan yang optimal pula. Pada saat pelatihan dilakukan sesi tanya jawab, diskusi dan sharing antara peserta yaitu Mitra UMKM Yaahftics dengan instruktur. Hasil yang diperoleh dari pelatihan ini Mitra telah mampu menentukan harga produk dengan keuntungan yang optimal.

Kegiatan Penyuluhan Pentingnya Diversifikasi Produk dan Manfaat Labu Kuning (Cucurbita Moschata) dan demo diversifikasi produk olahan labu kuning juga dilakukan Tim Pengabdian kepada UMKM Mitra (Yaahftics) dan masyarakat sekitar UMKM Mitra. Kegiatan penyuluhanpenyuluhan dan demo dimaksudkan agar timbul kesadaran Mitra dan masyarakat sekitar untuk melakukan diversifikasi produk olahan dari labu kuning pada output bisnisnya maupun sebagai alternatif pangan sehari-hari. Penyuluhan Pentingnya Diversifikasi Produk ini disampaikan oleh penyuluh Siti Khadijah Hidayati Nasution, SP., M.Si. kepada Mitra Yaahftics dan masyarakat sekitar Mitra. Hasil yang diperoleh dari Penyuluhan Pentingnya Diversifikasi Produk ini, Mitra dan masyarakat sekitar Mitra telah faham betapa pentingnya diversifikasi produk bagi suatu 
UMKM atau suatu bisnis dalam mempertahankan usahanya di tengah persaingan pasar yang semakin ketat.

Penyuluhan Manfaat Labu Kuning (Cucurbita Moschata) juga disampaikan oleh penyuluh Siti Khadijah Hidayati Nasution, SP., M.Si. kepada Mitra UMKM dan masyarakat sekitar Mitra UMKM agar Mitra dan masyarakat sekitar Mitra faham bahwa labu kuning memiliki potensi sebagai bahan pangan alternatif dan mempunyai banyak manfaat bagi kesehatan tubuh manusia. Hasil yang diperoleh dari Penyuluhan Manfaat Labu Kuning (Cucurbita Moschata) ini, Mitra dan masyarakat sekitar telah faham akan manfaat labu kuning bagi kesehatan tubuh manusia dan sebagai bahan pangan alternatif.

Disamping itu dilakukan juga kegiatan demo/praktek diversifikasi produk olahan labu kuning agar Mitra dan masyarakat sekitar Mitra mengetahui beberapa jenis contoh produk olahan labu kuning dan mengetahui cara pengolahannya. Beberapa resep produk olahan labu kuning yang telah diberikan Tim Pelaksana Pengabdian dipraktekkan/didemokan oleh Mitra kepada masyarakat di sekitar Mitra. Demo/praktek ini diberikan kepada masyarakat dalam upaya agar masyarakat tertarik untuk mendiversifikasikan pangannya dari beras dan non beras lainnya ke labu kuning yang sangat bermanfaat untuk kesehatan tubuh manusia. Disamping itu demo ini dilakukan agar masyarakat termotivasi untuk melakukan pengembangan usaha kuliner rumah tangga untuk meningkatkan pendapatan keluarga. Hasil yang diperoleh dari demo diversifikasi produk olahan labu kuning ini masyarakat merasa senang sekali telah memperoleh beberapa contoh produk olahan labu dan cara pengolahannya serta mereka termotivasi untuk melakukan usaha kuliner rumah tangga untuk meningkatkan pendapatan keluarga.

\section{KESIMPULAN}

\subsection{Kesimpulan}

UMKM rumah tangga memiliki peranan yang penting dalam perekonomian Indonesia. Peningkatan kapasitas produksi serta diversifikasi produk menjadi salah satu hal yang wajib dilakukan oleh UMKM untuk dapat bersaing dengan industri produk makanan yang sudah ada. Oleh karena itu kesimpulan dari kegiatan pengabdian ini adalah:

1. Hibah oven dan mixer dapat meningkatkan kapasitas produksi Mitra.

2. Setelah adanya penyuluhan pentingnya diversifikasi produk dan praktek diversifikasi produk olahan labu kuning, Mitra telah mampu melakukan diversifikasi produk olahan labu kuning.

3. Mitra telah mampu menentukan harga pokok penjualan

4. Masyarakat sekitar Mitra merasa senang telah memperoleh beberapa contoh produk olahan labu dan cara pengolahannya serta termotivasi untuk melakukan usaha kuliner rumah tangga untuk meningkatkan pendapatan keluarga.

\subsection{Saran}

1. Perlunya perhatian dan keterlibatan pemerintah terhadap perkembangan UMKM.

2. Perlunya kerjasama lebih lanjut antara UMKM dengan pihak Perguruan Tinggi agar UMKM mendapatkan pelatihan pembukuan yang baik, Gugus Kendali Mutu, dan Penyusunan Permohonan HKI/Paten.

3. Untuk selanjutnya setelah UMKM mampu meningkatkan produksi serta mampu mendiversifikasikan produknya, maka perlu adanya edukasi tentang sertifikasi produk makanan halal yang dihasilkan oleh UMKM.

\section{UCAPAN TERIMAKASIH}

Dalam kesempatan ini kami mengucapkan terima kasih kepada Non PNBP Tahun 2019 sebagai penyandang dana dan segenap pihak yang telah membantu dalam pelaksanaan Pengabdian Kepada Masyarakat ini. Harapan kami semoga program ini dapat berlanjut dalam memanfaat google classroom bagi dosen dan mahasiswa di departemen Biologi FMIPA USU. 


\section{DAFTAR PUSTAKA}

Astawan, M. dan S. Widowati. 2011. Evaluation of Nutrition and Glycemic Index of Sweet Potatoes and Its Approriate Processing to Hyglycemic Foods. Indonesia Journal of Agricultural Science. Vol 12(1):40-46

Depkes RI. 1995. Daftar Komposisi Bahan Makanan. Departemen Kesehatan. Jakarta

Hendrasty, H. K. 2003. Tepung Labu Kuning. Yogyakarta: Kanisius

Suismono dan N. Hidayah. 2011. Pengembangan Diversifikasi Pangan Pokok Lokal. Pangan. Vol.20 (3) September 2011

Widowati, S. 2007. Sehat dengan pangan indeks glikemik rendah. Warta Penelitian dan Pengembangan Pertanian. Vol. 29 (3): 5-6 